\title{
RETÓRICA SANGRENTA: PENSAR A COMUNIDADE NA INGLATERRA DO SÉCULO XIII
}

\author{
Bloody Rhetoric: thinking Community in 13th Century \\ England
}

\author{
Prof. Dr. Leandro Duarte Rust (PEM/UnB) ${ }^{1}$ \\ Professor do Departamento de História \\ ORCID: https://orcid.org/0000-0002-7410-1635 \\ E-mail: leandroduarterust@gmail.com
}

Recebido em: 10/06/2020

Aprovado em: 20/07/2020

\begin{abstract}
Resumo: Poucos elementos são tão caracteristicamente medievais como o derramamento de sangue. Não é exagero. Imagine um chão coagulado ou a pele chapinhada de vermelho e observe. Pode-se pensar em uma trincheira francesa de 1916 ou no senado romano dos idos de março, mas dificilmente se deixará de conceber a cena com referências medievais, sejam elas uma espada sobre a cota metálica, um castelo como câmara, uma cruz vestindo a armadura, um viking como saqueador ou um inquisidor como torturador. Embora seja alimentada por estereótipos, essa associação não pode ser reduzida a uma compreensão ultrapassada ou uma simplificação grosseira. Não se trata de simples resíduo da reputação "Idade Média, Idade das Trevas". Afinal, o sangue é, de fato, um elemento recorrente nos registros históricos deixados por aquele período. Há quase um milênio, narrar a realidade ou tentar criar uma memória sobre como as coisas se passavam implicava notar a presença desse líquido vital. Por quê? Eis a pergunta que este artigo tenta responder. Para isso, foi pensado um estudo de caso, uma análise detida sobre a história de um crime ocorrido no reino inglês no início do XIII. Trata-se de uma história sobre o enriquecimento cristão, a identidade do pecado, a natureza do crime, a relevância do duelo, a autoridade do milagre. Uma história pródiga em detalhes, densa em personagens e, como tal, suficiente para que seja testada uma hipótese: na Idade Média, narrar o sangue era uma maneira de pensar a comunidade cristã.
\end{abstract}

Palavras-Chave: Idade Média; Sangue; Comunidade; Século XIII.

Abstract: Few elements are as characteristically medieval as bloodshed. To state this is not an exaggeration. Imagine a coagulated floor or a red sprinkled skin and then observe, one might think of a French trench of 1916 or the Roman Senate of the Ides of March, but one will scarcely not conceive the scene with medieval references, whether they are a sword over a chainmail, a castle as a chamber, a cross over the armor, a Viking as a looter or an inquisitor as a torturer. Although all of this is fueled by stereotypes, such an association cannot be reduced to outdated understanding or gross simplification. This is not a mere residue of the "Middle Ages, Dark Ages" reputation. After all, blood is, in fact, a recurring element in the historical records left by that period. Almost a millennium ago, narrating reality or trying to create a memory about how things were indeed involved noticing the presence of this vital liquid. Why? Here is the question this article tries to answer. For this, a case study was selected, an analysis held on the history of a crime occurred in the English kingdom at the beginning of the $13^{\text {th }}$ century. It is a story about Christian enrichment, the identity of sin, the nature of crime, the relevance of the duel, and the authority of the miracle. A lavish story in detail, dense in character and, as such, enough to test a hypothesis: In the Middle Ages, narrating the blood was a way of thinking of the Christian community.

Keywords: Middle Ages; Blood; Community; 13th century. 


\begin{abstract}
"Algumas interpretações são escritas em sangue e correm sob uma garantia de sangue como parte de sua força de validação."
\end{abstract}

Robert Cover, 1983.

\section{O que há em um nome?}

Do século XII em diante, os cristãos do mundo latino "desenvolveram uma paixão pelo sangue". Essa frase, uma ligeira adaptação de uma ideia escrita não faz muito tempo por Gil Anidjar, toca diretamente o nervo de uma questão decisiva para a vida ocidental: como e por que a história da Cristandade se tornou uma história da presença massiva do sangue? Contudo, antes de tatear respostas, uma precaução: é preciso resistir ao fascínio pela cronologia. Ela não é primordial. O alerta pode soar estranho - afinal, que historiador recomendaria desapego a datas, certo? Pode ser. O estranho da advertência, porém, não a torna menos pertinente. Substitua-se "século XII" por século IV, VIII ou XVI, e o que há de mais relevante persiste, inalterado: o alcance antropológico da afirmação. A frase mira uma caracterização: o que explica que a Cristandade tenha encontrado no nome "sangue" o objeto de uma paixão social, uma referência que ela replica por quase toda parte, algo fundamental para dar sentido ao mundo e à vida? Como dizíamos, o crucial é a amplitude da pergunta, as proporções quase sem fim. Não é tarefa fácil fixar o ponto de partida para a explicação, chega a ser desencorajador projetar o repertório de temas necessários para percorrê-la até uma conclusão (ANIDJAR, 2016, p. 69. Ver ainda: MEYER, 2005).

Talvez seja justamente para contornar tal complexidade escorregadia que muitos autores e leitores concordam em reduzi-la, contê-la nas dimensões mais manuseáveis de um questionamento envolvendo a religião e a intolerância. No caso, acredita-se que essa dúvida poderia ser reescrita com termos mais familiares, mais práticos, já que formulados há séculos por autores a respeito dos quais muitos entre nós já ouviram falar. Um autor como Voltaire: "por que o monstro da intolerância habitou a lama da caverna ocupada pelos primeiros cristãos?". Mas isto dificilmente seria útil. Pois a dúvida muda quando assume a feição desse velho conhecido iluminista que é a crítica da religião como refúgio para o fundamentalismo e a violência. Esse outro modo de formular a pergunta faz mais do que polemizar. Ele enquadra o assunto de modo singular. (VOLTAIRE, 2009, p. 32)

Acontece que há aí uma distinção tácita: a de que a intolerância preexiste à religião como fenômeno independente, dotado de origem própria, algo com o qual a crença entra em contato e que pode ou não ser incorporado por ela. E é justamente ao definir tal relação de absorção como o essencial a ser explicado, que a formulação opera uma redução. Pois o desafio, agora, consiste em percorrer dois atos de pensamento: um, descobrir que forças teriam movido certas modalidades da intolerância (como exclusão, opressão, repressão e guerra) para junto da religião e, dois, o que eventualmente determinou que essa última as assimilasse e justificasse. Assim, eis a história convertida em uma matemática elementar, uma análise combinatória: a relação cristã com o sangue poderia ser explicada como uma combinação de etnocentrismo e imaginário do pecado ("direito de sangue"), ou de guerra justa e escatologia ("cruzada") ou de direito imperial e regime pastoral ("inquisição"). No fundo, trata-se de uma mesma pergunta aplicada a diversos casos: como as supostas fontes da intolerância (o etnocentrismo, a guerra justa, 
o direito imperial) foram absorvidas por aquilo que se presume ser puramente religioso (o imaginário do pecado, a escatologia, o regime pastoral)? Como se pode ler ao longo de Campos de Sangue: Religião e a História da Violência, conhecido livro de Karen Armstrong, formulado assim, o problema ganha contorno mais preciso, mas igualmente mais estreito - além de ideologicamente engajado (afinal, a religião não pode ser, ela própria, uma fonte de intolerância?) (ARMSTRONG, 2016).

Claro que uma "paixão pelo sangue" implica maneiras de lidar com a intolerância e a violência. Mas ela envolve muito mais, repercutindo ainda mais longe. Tudo depende de como se lê "sangue". A palavra não foi escrita como o nome de uma coisa líquida ou matéria coagulante, mas como significante. A questão, portanto, é um convite a explorar as razões de sangue ter se tornado um significante tão recorrente na cultura cristã a ponto de conferir sentido à experiência acumulada em diversas dimensões da vida. Na teologia, uma vez que as ideias sobre a condição humana, a realidade metafísica, a transformação da existência e a distinção dos seres ganham forma através dos significados de "o sangue de Cristo", "o sangue dos mártires", "a remissão pelo sangue", "o sangue dos inimigos", o "sangue de bodes e bezerros". Na economia, onde se pode considerar que o "dinheiro é o sangue da comunidade" - uma ideia cara à Cristandade dos escolásticos aos fisiocratas. Na política, afinal, Hobbes não assegurava que a propriedade e os bens móveis deveriam ser pensados como aspectos vitais à nutrição do Leviatã, "como a corrente sanguínea de um Estado"? No laço de pertencimento, isto é, na própria identificação do vínculo social, seja como grupo, raça ou pátria; já que a fronteira entre o nativo e o estrangeiro pode ser concebida como uma diferença entre sangues, como indica a Limpieza de Sangre ibérica ou a One-Drop Rule norte-americana. Na vida intelectual, pois um título como As Veias Abertas da América Latina pode marcar uma geração como uma poderosa evocação sobre a Economia Política. A questão, portanto, tem amplo espectro antropológico. Como e por que, em algum momento da história, ser cristão era nutrir uma sensibilidade diferenciada a respeito do sangue? (ANIDJAR, 2016, p. 79-135. Ver: JOHNSON, 1966; GALEANO, 1979; ROUX, 1988; BRADBURNE, 2001; ERIKSEN, 2017).

Uma resposta pode ser encontrada no início do século XIII, junto às histórias que os súditos da realeza inglesa contavam uns aos outros. Em meio às centenas conhecidas, há uma cuja preservação para a posteridade "talvez seja caso único", como notou Edward Wheathley. Trata-se do relato pormenorizado de uma desoladora - e, por vezes, dantesca! - trajetória da juventude à velhice. A história foi escrita, não se sabe por quem, como recordação de um dos muitos milagres atribuídos a São Wulfstan, bispo de Worcester que faleceu nos anos 1090 como um dos últimos anglo-saxões a ocupar uma posição de poder na Inglaterra conquistada pelos normandos. Ambientado no início do século XIII, o relato foi acrescido ao manuscrito da Vita Wulfstani, a "Vida de [São] Wulfstan" composta pelo monge Guilherme de Malmesbury muitas décadas antes. A história investigada a seguir foi composta por um monge beneditino que, em algum momento após 1207, se viu diante da incumbência de continuar uma compilação de vidas dos bispos de Worcester; trabalho iniciado anos antes por outro monge, chamado Senatus. Não era, portanto, criação de um autor, mas resultado de um longo processo de sedimentação textual, de escritas, reescritas, adaptações (WHEATHLEY, 2010, p. 175176; HARDY, 2012, p. 72; DAMIEN-GRINT, 2019).

A narrativa detalhada permite fundamentar e confrontar uma hipótese de trabalho capaz de responder à pergunta mencionada nos parágrafos anteriores. Trata-se da seguinte possibilidade: em uma narrativa como a dos milagres de São Wulfstan, o 
sangue é parte de uma retórica formulada para pensar, em primeiro lugar, a organização da comunidade cristã. A dramatização dos danos infligidos ao corpo ou a caracterização de uma medida para a tragédia pessoal seriam efeitos narrativos secundários; na realidade, seriam funções narrativas auxiliares. Isto significa que o aparecimento textual do sangue era um modo de pensar, engenhosamente, as identidades, a dominação, a riqueza, o consenso - não apenas a legalidade ou a intolerância, como explorou Paul Hyams, autor de um estudo pioneiro sobre essa história. À luz dessa hipótese, o nome "sangue" era uma figura genérica, uma aparência universal que conferia sentido a problemas particulares. Quando um medieval falava sobre isto, ele, provavelmente, absorvia e respondia a desafios sociais, lidando com tensões criadas pela vivência coletiva, em comunidade (HYAMS, 1985, 2003).

Aí estão o problema, a fonte histórica, a hipótese e o parâmetro conceitual. Temos as coordenadas de pesquisa. Hora de iniciar a investigação. Vejamos, então, se a retórica sangrenta era uma maneira de se ocupar da vida em comunidade.

\section{Um batismo mundano}

Esta história miraculosa inicia-se com o ingresso de um jovem na vida econômica. O protagonista, Thomas, residia não muito distante da cidade de Tewkesbury, interior do condado de Gloucester. A localização da moradia permite extrapolar o registro histórico e sugerir que Thomas tenha crescido rodeado por um horizonte de prosperidades. Afinal, o condado era formado por paisagens agrícolas dinâmicas, crescentemente integradas aos ricos circuitos mercantis do sudoeste inglês. E não era preciso ir muito longe para ver essa realidade ganhar forma humana. Bastava tomar a estrada até a localidade mais próxima. Situada às margens da desembocadura do rio Avon no caudaloso rio Severn, Tewkesbury era um permanente atracadouro para os comerciantes e artesãos de Shrewsbury, Evesham, Worcester e outras cidades de grande porte. Na passagem para o século XIII, as cadeias produtivas interioranas já não dependiam de eventos extraordinários, como a mobilização para a cruzada ou a edificação de uma abadia, para extrapolar o âmbito local. Conectadas pela crescente mobilidade humana, elas convergiam para a geração de riquezas flutuantes, que, por sua vez, avançavam sobre o cotidiano rural atrelando o valor das relações sociais ao ritmo das trocas e à circulação do dinheiro. A economia mercantil respondia por grande parte do estilo de vida senhorial (Ver: BRITNELL, 1993; HATCHER; BAILEY, 2001).

Mas a pujança material narra com cores ainda mais fortes as desigualdades sociais. Sob o impacto do dinamismo econômico, os homens descobrem contrastes agudos sob a aparência de diferenças opacas. Especialmente aqueles a quem leis e decretos asseguram um lugar acima da subordinação camponesa. Segundo o registro documental, Thomas era um desses casos: "um homem livre em sua condição, mas magro em sua constituição". A frase ressoa inquietante, algo ultrajada. Para a mente que narra, a compleição de Thomas parece incompatível com seu status jurídico, como se um homem não pudesse ser de fato livre permanecendo franzino. A liberdade não vinga no corpo que é imagem e semelhança da privação, de quem "mal obtinha o suficiente para si” - consta no documento. Essa não é a correta ordem das coisas; que devem, então, ser corrigidas, endireitadas. Razão pela qual entra em cena a figura de Estmar. Movido por "piedosa severidade", o pai de Thomas o expulsou de casa "para que ele 
respondesse por suas próprias necessidades". O que pode parecer um fraseado trivial é, na realidade, um enunciado capital, repleto de implicações de teor social. ${ }^{2}$

Pois, aqui, a severidade paterna é como a água de um batismo mundano. Observese. Redizendo antigos significados romanos, à maneira de um Salústio ou um Quintiliano, o relato faz a severidade emergir como virtude, como a excelência despojada de ternura. Essa sabedoria assumidamente rústica cumpre um papel dignificante, honrado: ela redime do desamparo material, purifica da falta de sustento. Honrado e, por conseguinte, piedoso. Ao caracterizar a conduta paterna, o relato parece entabular o entendimento notoriamente pagão que considerava piedoso não necessariamente o ato de ser indulgente ou comiserar-se pelo outro, mas, sim, o de impor obediência a um dever da espécie, instituir respeito à ordem natural da vida. A severidade de Estmar é piedosa porque opera uma transformação primária, tão decisiva para a natureza humana quanto um batismo para a alma: dar início a uma nova etapa da existência fundando o instante em que um jovem se torna responsável por ganhar o pão e persistir em um mundo regido pelo dinheiro. Banhado em severidade, esse jovem estava incorporado à vida econômica (Vita Wulfstani, 1928, p. 168. Ver ainda: MAY, 1988, p. 106-113, BALMACEDA, 2017, p. 48-72).

Thomas viveu a nova vida exemplarmente. Ele foi admitido a serviço do principal magistrado do reino, Geoffrey FitzPeter. O êxito é o indicador eloquente de uma posição social elevada. Os caminhos que conduziam ao grande salão do Justiciar chefe, o segundo homem do reino, eram todos aristocráticos. Colocado porta fora, Thomas não partiu de mãos vazias, pois tudo indica que levou consigo uma valiosa herança: a influência do pai no interior de alguma rede de alianças que se estendia até os grandes senhores do reino. Difícil precisar. No registro documental, Estmar consta como homem de posses estreitas, insuficientes, um proprietário incapaz de prover à família. Mas suas penúrias dificilmente condizem com a realidade da escassez camponesa. Na Inglaterra de 1210, quem buscava lugar na corte de um FitzPeter e quem tentava escapar à pobreza eram pessoas diferentes, para as quais o nascimento, $\mathrm{o}$ trabalho ou a obediência acarretavam realidades tão opostas como o céu e o inferno. Recomendado por sua posição, Thomas ascendeu rápido. Sujeito "consciencioso", reza a história, ele se destacou entre os que serviam no grande salão e logrou certa liderança junto ao séquito do magistrado. Tendo semeado virtudes, a colheita foi generosa: "ele enriqueceu (lucrifaciens) de muitas maneiras". Se o verbo lucrifacere comporta certo sentido metafórico, como se tratasse de riquezas espirituais, o que vem a seguir ancora a frase em sentido propriamente econômico. Reatemos a narrativa (WEST, 1966, p. 97156; CHURCH, 2015, p. 93-173). ${ }^{3}$

\section{Ser um bom cristão}

Os cinco anos na corte de FitzPeter transformaram Thomas em homem habilidoso na "busca de riqueza" (pecunie). Sua maestria era de tal ordem que, de volta à terra natal, ele "acumulou ainda mais riqueza (divitias) empenhando-se por assuntos [seculares]". As palavras pecunie e divitias, ambas traduzidas por "riqueza", eram referências textuais que, no século XIII, aludiam ao patrimônio acumulado respectivamente como dinheiro e como posses. Com isso, as possibilidades de 
significado se reduzem, afunilando na direção da conclusão: Thomas ampliou o patrimônio familiar, tornando-o, finalmente, superavitário, pródigo em recursos, ajustado à condição de um homem livre. Embora vinculado a uma corte, a um espaço que se poderia considerar feudal, tradicionalmente senhorial, esse novo patrimônio familiar era constituído pela riqueza flutuante que as cidades colocavam em crescente circulação local. O amadurecimento de Thomas é um trânsito sociológico, uma passagem do cotidiano agrário para um estilo de vida urbano. O jovem magricela de corpo e de bolsa retornou homem capaz de enriquecer, capaz de tornar-se abastado o suficiente para atuar como credor das linhagens de Gloucester. Quem "tomava dinheiro (pecuniam) emprestado dele" servia-se à mesa dos magnatas locais ${ }^{4}$ (Ver ainda: Ec. 5:9, na edição da Vulgata: GAROFALO, 1965).

A severidade é aí um valor expressivo - sociologicamente expressivo. Virtude que reforça outras virtudes, é o primeiro motor do ajustamento da existência de Thomas que, graças a ela, retorna à terra natal talhado sob medida para corresponder à aparência de um homem livre. Ela é o acontecimento ético que desencadeia o florescimento da autonomia e da capacidade cristã de edificar. Precisamente neste ponto, sua função no relato se torna reveladora, pois a severidade conduz a uma autonomia singular, material, que se faz real e tangível como enriquecimento. A plena participação na vida econômica é "o" indicador de que se alcançara o elevado nível de responsabilidade que a Igreja esperava dos laicos, como se pode constatar na frase citada no parágrafo anterior: ele "acumulou ainda mais riqueza, lidando com assuntos [seculares] à maneira de quem vive no século". . O caráter exemplarmente laico faz dessa autonomia uma qualidade essencial para a estruturação da vida comum cristã. Ao fazer da economia monetária teatro da edificação pessoal, qual palco de um engrandecimento moral, a história de Thomas parece dar razão aos revisores do chamado paradigma da "Revolução Comercial”. Expliquemos melhor.

Tendo alcançado projeção intelectual nas páginas de Der Moderne Kapitalismus, estudo publicado por Werner Sombart, em 1902, o paradigma da "Revolução Comercial" regeu os estudos medievais no século XX. Não era para menos. A imagem das décadas de 1150 a 1250 como o tempo de grandes reviravoltas, como a época em que uma inédita racionalidade do comércio, do lucro e do crédito revirou a sociedade de ponta a ponta, foi revista e ampliada constantemente. Sua credibilidade carregava as assinaturas de Michael Postan, Roberto Lopez, Maurice Dobb, Lester Little, Jacques Le Goff, Richard Sennett. Endossado por nomes de notoriedade invulgar, o paradigma permaneceu profundamente enraizado na escrita da história. Essa perpetuação fez com que muitas das conclusões que o integravam - certezas circunscritas e abertas ao debate como qualquer outra formulada pelos historiadores - fossem naturalizadas como um conhecimento suficiente e acabado, como o que há de consensual sobre aquilo que se desejaria saber. Entre elas, está a certeza de que, em se tratando do século XIII, o êxito econômico era uma força desestabilizadora do ethos cristão. Que o enriquecer individual necessariamente minava valores tradicionais como "fé, honra, mérito [...] e o poder do chefe da casa" - como afirmou Georges Duby ao narrar o impacto do "grande progresso" sobre a mentalidade medieval. Quem sabe, na Gália, tudo tenha transcorrido dessa maneira. No entanto, sob o céu inglês, há indícios de que a realidade fosse outra (DUBY, 1992, p. 163. E ainda: SOMBART, 1902; POSTAN, 1933; LOPEZ, 1976; DOBB, 1946; LITTLE, 1983; LE GOFF, 2004; SENNET, 2003. Para um panorama crítico sobre o paradigma em tela, ver MELL, 2007, p. 236-317). 
Ouvindo a história do jovem Thomas teria sido possível acreditar que a busca por dinheiro decorria do dever filial: não de ambição, ganância ou um apetite carnal. Daquele lado do canal da Mancha, a narrativa eclesiástica era capaz de inscrever a acumulação de dinheiro e bens na economia da salvação conferindo um caráter benigno à bolsa abalroada de moedas. Manejando um repertório ético elástico, versátil, a cultura clerical era capaz de sacralizar o sentido social da riqueza, que emergia ressignificada como uma maneira honrosa, piedosa, de ingressar na vida comum dos fiéis. A riqueza tem mais de um sentido teológico e os modelos para normatizar a vida comunitária eram plásticos o suficiente - isto é, ideologicamente plásticos o suficiente - para incluir as relações sociais atreladas a uma economia de mercado como condutas coerentes com a moralidade cristã. $\mathrm{O}$ dinheiro era algo mais do que uma referência a almas perdidas para a idolatria dos bens materiais, ele também era um tema de feitos admiráveis, de condutas instrutivas, comportamentos a ser imitados. O que costumava sequestrar o juízo e fazer dele escravo da cobiça poderia ensinar a obedecer a Deus. A história de Thomas se presta a essa leitura. Afinal, ele voltou para casa transformado. Era, então, um homem afortunado, abençoado, pronto para "regar as coisas acumuladas em benção no momento da semeadura, para colher mais ricamente na época da colheita". Lidando com a riqueza, sua existência teria, assim, cumprido uma promessa bíblica: "como semeardes, assim colhereis" - como consta na Bíblia. O celestial e o terreno se entrecruzavam no dinheiro. ${ }^{6}$ (Ver: Gálatas 6:7; 2 Coríntios 9:6. E ainda: TODESCHINI, 2002; PRODI, 2009; BROWN, 2015; NAISMITH, 2015, p. 17-38).

O batismo mundano rendia frutos ao ideal de comunidade. Afinal, o bom cristão era aquele que enriquecia. Retenha o leitor ou leitora essa última caracterização, pois ela será de grande relevância para esta análise. Por ora, sigamos o compasso da trama.

\section{Nem todos sangram}

Entre os que solicitavam empréstimos a Thomas estava "a esposa de seu senhor, Robert Northway". A dama é um personagem sem nome. A narrativa se recusa a proferilo. Porém, ainda que incógnita, ela cumpre um papel crucial e insuperável. Por meio dela o conflito entra na trama, trazendo consigo os desvios e as maldades que regerão o enredo. Redigida em letras de misoginia, escrita com o traçado que as mentes eclesiásticas então conferiam à prosa do mundo, esta história miraculosa aponta a natureza feminina - não o dinheiro, tampouco o enriquecimento - como razão para o erro e a iniquidade começarem a dominar entre os homens. É a dama, afinal, quem aparece corrompendo o vínculo social, quem estraga a integridade do contato possibilitado pela riqueza. Ela é a responsável pela degeneração da proximidade com Thomas: "ela o seduziu para a intimidade do adultério e o manteve enredado às armadilhas de Vênus". O adultério perdurou por dois anos, até que "a graça de Deus interveio e tornou o remorso insuportável". Em amarguras, Thomas buscou a cura para sua alma doente: lançou-se aos pés de um padre, confessou o pecado e cumpriu a penitência imposta. O fez não uma, mas cinco vezes. Era preciso retornar ao "precioso conselho" clerical constantemente, pois o pecado não se afastava, continuava a rondá-lo, incitando-lhe a mente com o perigoso canto carnal: recusando-se a aceitar o fim da 
relação, a dama insistia em retomar o enlace. As investidas, inclusive, ganharam fôlego com o falecimento de Robert Northway. Viúva, a mulher "evocava [o homem que voltara rico] para casar-se com ela", .

Com o desejo domado pela penitência, Thomas resistiu a cada investida da "filha da antiga Eva" - a expressão é o mais próximo de um nome para a dama alcançado pela narrativa. A rejeição, todavia, ultrajou duplamente a viúva, que considerou desprezados seu sentimento e sua posição social. O lamento e a vergonha cultivaram diariamente uma hostilidade mortal. Era o início de outra semeadura e, desta vez, a colheita seria sinistra: "ela disfarçou tal sentimento [...] como apenas uma mulher pode, adiando a vingança". O tempo passou, regrando silenciosamente o apetite por desforra. Foram anos de espera pelo momento oportuno. Mas a demora foi recompensada. Após longa viuvez, a dama casou-se. O marido, George, é descrito como "homem astucioso, habilidoso na dissimulação". Os predicados não são somente marcas de uma índole, mas um anúncio de que a história entra em nova fase, pois a propensão feminina para o mal ganhou um protagonista. Com a figura de George, o antagonismo passa da espera à ação; o ódio represado pode, a partir de então, jorrar pelas decisões de um agente dotado da prerrogativa masculina de agir à vista de todos. O que se segue é uma escalada de tensões ${ }^{8}$.

O relato não leva mais do que um punhado de palavras e já na frase seguinte surge a cena de George descobrindo o passado de adultério entre a esposa e Thomas. A notícia desperta uma suspeita ferina, um tormento para o "zelo marital". E foi assim, com a mente ouriçada, brotando espinhos de um ódio irrefreável, que, um dia, George ficou lado a lado com Thomas. O encontro tem a aparência caprichosa de um acaso, uma trivialidade. Ao menos é o que diz a história: "um dia, quando se encontraram para comprar uma cerveja ou duas...". Beberam juntos. Na realidade, embebedaram-se. E a embriaguez fermentou o ódio do marido atormentado 9 .

Após cada um tomar o seu caminho de casa, George decidiu seguir Thomas pela estrada. A certa altura, a perseguição deu lugar a uma emboscada. George se lançou sobre o rival, atingindo-o na cabeça com um enorme bastão. O golpe descera seco, mas isolado, pois o agressor se deteve. A poucos passos, mantinha-se ameaçador, vociferando que os próximos movimentos seriam mais brutais. Após grunhir de dor, Thomas reagiu, mas não foi com as mãos. Com a "devida moderação", disse a George que fosse embora, pois sabia que a "força da cerveja o levara a cometer tal ato"; poderia partir ileso, desde que "não acrescentasse qualquer outra dor àquela provocada pela ferida" aberta em sua cabeça. Foi em vão. Ensurdecido pela ira, o agressor voltou à carga. Um movimento súbito acertou o ombro de Thomas, que sentiu nos músculos a certeza de que "se não repelisse força com força, correria o risco de ser morto". O senso de perigo fez suas mãos encontrarem o cabo do machado que trazia consigo e, um instante depois, a extremidade afiada já riscava o ar desenhando a trajetória de um arco letal. A investida, porém, foi desmedida. O golpe saíra largo, demasiado amplo, indo além do que exigia a silhueta do agressor. A lâmina ceifou o vazio atrás do ombro de George, "sem feri-lo"; mas, ao ser puxada de volta, raspou-lhe o braço: "o suficiente para derramar sangue". Sangue e coragem, já que o corte o pôs em fuga. Ele correu para um abrigo visto da margem da estrada, um lugar que era usado para armazenar colheitas. George permaneceu ali por um momento e, em seguida, escapuliu em disparada para longe $\mathrm{e}^{10}$. 
Paremos aqui. A essa altura da história está consumada uma clivagem de extrema importância. Sua relevância é de tal ordem que tornará qualquer distinção entre vencido e vencedor irrelevante. Trata-se da separação entre quem sangra e quem não sangra. Essa diferenciação é objetiva. George é o único cujas veias falam ao mundo. Reparemos no léxico. A história mostra Thomas "atingido na cabeça" (percussit in capite) e, a seguir, queixando-se de uma "dor" (dolorem) condizente com a de uma "ferida" (vulneris). Mas em momento algum o vemos coberto por uma cor vermelha e quente. A pele está fendida, mas o sangramento - se é que ocorreu - é invisível, está implícito. A palavra sanguis não é usada. Com George se passa o contrário. O golpe sofrido havia sido de raspão, o corte, provavelmente mínimo. Mas foi "o suficiente para derramar sangue" (usque ad sanguinis profluxum). A redação latina é explícita, e sua sonoridade desata no ouvido uma sensação vívida, tangível, convidativa à imaginação de um tal modo que a tradução talvez não tenha alcançado: a cena de um fluxo (profluxum) de sangue. Assim, somos levados a conceber que dois homens se atracaram em uma luta mortal, trocaram golpes e rasgaram o ar com um bastão e um machado, mas, enfim, o sangue vazou de apenas um corpo. Eis a diferença que separaria radicalmente os envolvidos e, no desenrolar da trama, imporia identidades diversas a eles e a seus patrimônios. Como? Retornemos à história.

\section{A verdade pulsa nas veias da hierarquia}

George fez da fuga uma catilinária campestre. Abordou todos que encontrou pelo caminho, exibindo com alarde o braço ensanguentado e atando o nome de Thomas àquela violação. A narrativa é novamente explícita ao mencionar o que ele exibia aos olhos de cada um dos passantes: não propriamente o braço ou o corte, mas "a efusão de seu sangue" (sanguinis sui effusione). A cada abordagem, a cada atenção magnetizada, a história era recontada e, ondulando entre queixas e espalhafato, assumia uma versão "completamente diferente do ocorrido". À nova feição dos fatos, George havia sido vítima de um facínora. Em total inocência, ele dizia ter sido ferido por um criminoso do pior tipo, um "violador da paz do rei". A verdade não poderia ter sido mais adulterada, distorcida. Bem... segundo consta na narrativa, poderia, sim. Pois um dissimulador astucioso não se deixa intimidar por limites de bom senso. Uma vez em Northway, George expandiu a mentira. Ele incitou a vizinhança agregando gravíssimos detalhes à trama deturpada: Thomas, dizia ele, havia "invadido violentamente sua casa" - o que, como era amplamente conhecido, configurava crime de "violação da paz do rei" - e, ardilosamente, levou seus bens "como um ladrão, infligindo uma ferida mortal enquanto defendia sua casa". A "traição" à verdade alcançara novo patamar".

A história, que até então fora apenas revirada, estava agora recriada noutro palco, pressupondo outra motivação e transcorrendo como um ato radicalmente diverso. Mas o aspecto historicamente mais relevante não é a extensão da fraude. É, isto sim, o fato dela ser narrada como mentira plausível. Ainda que extravagantemente absurda aos olhos do narrador onisciente, ela é apresentada como crível, aceitável. Por isso, após ouvi-la, "uma assembleia inteira de homens ergueu-se contra Estmar, acusando-o de proteger e auxiliar [o filho nos crimes cometidos]" 12 . O pai foi levado a Gloucester e entregue ao Sheriff, que imediatamente o trancafiou em uma cela; destino partilhado pelo filho logo em seguida. Cabe, então, perguntar: o que tornou essa história contada tão persuasiva? O que conferiu tal plausibilidade a uma versão fraudada? O que 
determinou que fosse o malicioso George - e não o obediente Thomas - o personagem capaz de satisfazer uma expectativa pública pela verdade? A resposta pode estar em um elemento: o sangue.

À medida que a história transcorre, o aparecimento do sangue estabelece as coisas em uma ordem específica. E essa ordem tem um efeito normativo sobre o texto, ou seja, ela deve ser reconhecida e acatada, mesmo por aquele que a desaprova, como é o caso do narrador. Seja ele quem for, sua pena é de um partidarismo inequívoco. Ela faz de George uma verdadeira síntese humana do pecado: "ira", "malícia", "mentira", "traição". Quase se pode imaginar um redator de semblante contrariado, contorcendo os lábios e franzindo o cenho enquanto faz a história ganhar forma sobre o pergaminho. Isso faz sentido. Pois a lição deixada pela trama até aqui parece ser a de que George, obstante ser reprovável, tinha a ordem jurídica a seu favor. Por quê? Porque ele sangrara. Por tudo que foi descrito, pode-se afirmar que o sangue surge na história como a marca de uma transformação. Sua ocorrência é um acontecimento em si, é o ponto de passagem do corpo de um estado para outro.

Melhor dizendo, o sangue é a marca indelével e inegável do trânsito jurídico entre ser uma pessoa, uma entre as muitas integrantes da comunidade, e ser "sujeito de direito", alguém cujas demandas repercutem diretamente sobre a lei e a autoridade. O sangue não é um conceito ou um dado objetivo. Ele é uma figura de evocação. Antes de ser um evento orgânico, efetivamente fisiológico, sangrar é um acontecimento retórico: uma forma para evocar e provocar a justiça. Isso significa que a incorporação da alusão ao sangue em uma narrativa como essa não ocorre, necessariamente, para retratar a literalidade de uma cena ou para descrever a violência com realismo. Aliás, um comentário: "violência" é o nome reservado pela história à violação da propriedade não dos corpos! O advérbio violenter ("violentamente") diz respeito a uma casa invadida e aos bens alegadamente surrupiados. Na Inglaterra do século XIII havia uma consciência apurada de rejeição da violência, mas ela não implicava um ideal de inviolabilidade física. A violência e a conduta sangrenta não eram realidades coincidentes. A alusão ao sangue - e aqui retomamos o raciocínio - era uma operação jurídica, uma maneira de indicar que uma pessoa acabara de se tornar o reflexo vivo das normas comunitárias (McCALL, 1996, p. 192; RUST, 2018. Sobre o conceito "figura retórica": FAHNESTOCK, 1999).

\section{Sanguinificar o direito}

Aqui, a história fatídica de Thomas fez do sangue um Principium Individuationis, um "Critério de Distinção". Não é a descrição do sangramento que confere relevância à figura de George. Pode-se arriscar o oposto. Porque a figura de George detém um status superior, ele é o único que terá a pele coberta de sangue. Ambos foram feridos. O texto emprega a mesma palavra para as marcas dos golpes recebidos: vulnus, um dos vocábulos mais recorrentes para o que entendemos por "ferida" ou "corte". Contudo, a narrativa só permite ver o líquido vital escorrendo de uma delas, daquela que havia 
rasgado a pele de quem detinha uma posição de senhor. Afinal, cabe não perder de vista que o casamento com a viúva faz George ingressar na trama ocupando a posição onde Thomas reconhecia o "seu senhor" (Domina sua). Talvez o sangue seja parte de uma descrição realista; talvez ele esteja lá porque efetivamente foi testemunhado. Que seja. Mas ele é algo mais: o sinal que expressa e localiza outra mensagem, que a hierarquia social havia sido concretamente ameaçada. Esse aparecimento textual modela um senso de gravidade, instrui sobre como a comunidade deveria conduzir sua existência, selecionar suas prioridades e mobilizar as instituições públicas. A menção ao sangue é ideologicamente seletiva, pois realça uma violação corporal específica, a de quem ocupa o escalão aristocrático mais elevado. Como se a seiva que circula no interior dos corpos se tornasse mais vermelha e visível à medida que se ascendia no interior das elites. A narrativa sobre o sangue tornava tangível o limite de uma ordem jurídica senhorial, isto é, ela demarcava o ponto em que as garantias legais aos privilégios ingressavam em território hostil (Ver: ANIDJAR, 2016, p. 26).

Esse é um traço cultural relevante. Nas terras inglesas do século XIII, quando se descrevia enfrentamentos, execuções e até mesmo batalhas, as descrições faziam mais do que formular uma medida de tragédia ou sofrimento. Narrando o sangue, integrantes das elites, sobretudo do clero, "sanguinificavam" a compreensão do mundo, elaborando uma espécie de mitologia vermelha, isto é, uma transposição de planos culturais de modo que o individual se tornava espelho do comunitário, o corpo, uma figura das normas. E assim entretecida, essa maneira de ler o mundo era já uma força capaz de guiar poderosamente a ação, estabelecendo padrões de comportamento. Afinal, o sangue evocava e provocava. Ele era como a cicatriz de Ulysses observada pelas lentes magistrais de Erich Auerbach: um código onde eram guardadas muitas histórias (AUERBACH, 2001. p. 1-20).

Filho e pai pagaram um preço pelo encarceramento. Não é modo de dizer. A julgar pela narrativa, trata-se literalmente de dinheiro, já que eles foram soltos "depois de prestar juramentos e dispor de sua bolsa". Thomas voltaria a ser preso diversas vezes. Em todas as ocasiões, terminou solto "graças à intercessão dos cortesãos a que servira e após dispor de seus bens e direitos em negócios" ". A perda da riqueza era uma etapa da reparação dos valores comunitários. A preservação da norma - no caso, da inviolabilidade da ordem hierárquica - ganha contornos reais por meio de cobranças em moedas e bens. Em outras palavras, afetando diretamente um dos indicadores mais eloquentes da fibra moral de uma pessoa.

Precisamente aqui é preciso recordar aquela caracterização, formulada algumas páginas atrás, a respeito do entrelaçamento entre a riqueza e os modelos comportamentais - lá por onde abordamos o paradigma da "Revolução Comercial". Pois ela aprimora nossa avaliação sobre a dimensão da degradação social acarretada por tal sucessão de prisões e pagamentos. Quando se crê que o bom cristão é aquele que enriquece, a perda patrimonial torna-se um estigma social agudo; não apenas a punição para um crime, mas a marca de uma existência em perdição. O fluxo vermelho que escorreu do corte no braço de George gotejou sobre o batismo mundano de Thomas. Conspurcou sua existência comunitária. O sangue evocou e provocou uma excomunhão profana. O que a severidade fez, poderia ser desfeito, pois a riqueza, essa substância virtuosa, não deveria mais permanecer em mãos impuras, manchadas de transgressão. Ao trazer de volta o pai, as riquezas e os cortesãos, a história confrontou o protagonista com o berço de sua existência. E o retorno infeliz às origens pode ser visto como um fechamento, a consumação de uma certeza. Expliquemos melhor essa última afirmação. 
A vida de Thomas atingiu um ponto sem volta. A denúncia formal, os sucessivos encarceramentos e principalmente as destituições patrimoniais eram marcas indeléveis de ilegalidade. De agora em diante, ele não podia mais andar de cabeça erguida nos caminhos da justiça. Sua degradação pública estava consumada, não obstante injusta - e esse é um aspecto que não se pode deixar escapar! A narrativa é decididamente maniqueísta quanto aos rivais. De um lado, o filho da severidade, o penitente exemplar, moderado até mesmo embriagado, combatente da luta justa. Do outro, o esposo da hostilidade, o mentiroso sem peia, malicioso até mesmo sóbrio, combatente da luta desigual. A virtude versus o vício. Um maniqueísmo pleno, que, no entanto, é sobrepujado por outra atitude: o conformismo. A história conforma todos os personagens ao cumprimento da lei. Em momento algum a operatividade jurídica é contestada ou desacatada. Da acusação formulada em assembleia à denúncia ao Sheriff, das prisões em Gloucester aos pagamentos pela soltura, nada é tido como ilegal ou mesmo ilegítimo. Certamente lamentável, mas não ilegal. O envolvimento dos cortesãos e a cessão do patrimônio são narrados sem menção a contestações e recusas. Era efetivamente um caso de violação da paz do rei. O sangue de um aristocrata tornava crível a notícia de invasão e roubo à casa de "um senhor", um caso claro de violentia. E a violência deveria ser punida. Ou seja, o traçado que predomina é o de normalidade legal. A mensagem deixada, de resignação: a justiça tem outros fundamentos além da moral e da retidão; a lei, mesmo quando não se faz virtuosa, deve ser obedecida. Havia razões suficientes para que a aparência dos acontecimentos fosse tomada como realidade, ainda que não houvesse veracidade naquela versão. Havia muita gravidade. Pois havia sangue.

Um de um tipo muito singular.

\section{Na cicatriz senhorial, a anatomia da paz}

Até este ponto, a história teria se passado no tempo do rei João I, conhecido como "João, Sem-Terra". A expressão carregava uma memória duplamente ultrajante. Por um lado, recordava o minguado patrimônio recebido em testamento por ser o filho caçula de Henrique II; por outro, tornava impossível esquecer a imensidão dos territórios angevinos ("ingleses") perdidos para o rei da Francia. Quando faleceu, no outono de 1216, o "Sem-Terra" legou ao filho não só um reino encolhido, mas uma coroa encurralada por revoltas aristocráticas e uma autoridade corroída por acusações de tirania. A gravidade da situação disseminou um senso de urgência na corte do herdeiro: era preciso restaurar rapidamente a legitimidade monárquica e uma das condições para isso consistia em fazer da coroação do novo rei o portal para um novo tempo. Era preciso se certificar de que as elites, rurais e urbanas, compreendessem que as discórdias, os abusos e os fracassos seguiram o velho rei para a sepultura. Que uma idade gloriosa tivera início. Mas não seria simples mudar a feição do tempo. Reconquistar as terras perdidas não era uma alternativa realista. Buscá-la seria lançar-se à sorte das armas contra um rival, a linhagem francesa dos capetíngios, que havia prevalecido por duas décadas e cuja superioridade militar era engrandecida por uma aura de invencibilidade conferida por triunfos recentes, como na célebre batalha de Bouvines, ocorrida em 1214. Ademais, a glória de conquistador parecia inalcançável no próprio reino, tendo em vista a marcha anual do número de castelos reais controlados por forças senhoriais, muitas abertamente rebeladas. Pressionada pelo campo de batalha, 
a regência recentemente instaurada - Henrique III, o sucessor do "Sem-Terra", foi coroado com nove anos de idade - canalizou esforços noutra direção (Vita Wulfstani, 1928, p. 170; STRICKLAND, 1994, p. 56-79; SEEL, 2012; CHURCH, 2015; MALÝ, 2016, p. 7-20).

O novo tempo seria, de fato, uma pacificação. Não pela espada, mas pela palavra. Já em 1217, o governo regencial pôs em movimento sucessivas decisões que pareciam ter o propósito de imitar o século XII e reviver a era de um antepassado, Henrique II, quando o rei e a corte eram reconhecidos como o vértice de onde partia a rede de magistrados e procedimentos de justiça que abarcava todo reino. Isto é, quando as sentenças que puniam malfeitores e defendiam inocentes eram imediatamente associadas ao ocupante do trono. O estreito campo de ação à disposição da realeza seria redirecionado para reaver a posição outrora ocupada no interior da Common Law, a intrincada teia de relações operativas do direito anglo-normando. Entretanto, mesmo quando não se fia pela espada e pela batalha, a pacificação é tarefa árdua, espinhosa e, amiúde, atroz. Mesmo quando tem a palavra por instrumento, a paz precisa ser extraída da imperfeição humana, desentranhada à força de vidas pecadoras, o que deixa um rastro de dor e morte - assim ensinava a tradição cristã. Não seria diferente na história de Thomas. Gloucester foi uma das localidades a receber os magistrados da regência. Como um dos cenários escolhidos para a ressurreição jurídica da realeza, o condado se tornou parte da via-crúcis da natureza humana (HUDSON, 2018, p. 14-25. Ver ainda: RUST, 2018, p. 56-86).

A notícia da chegada dos juízes do rei fez o ódio de George sair da toca. Ele, "que não esquecera a hostilidade", encontrou outra oportunidade para atender às exigências do rancor - assegura a narrativa. Afinal, os novos magistrados não se omitiriam perante um caso de "violação da paz do rei". Ao contrário. Investidos em suas funções pela autoridade monárquica, eles seriam compelidos a agir com veemência. George, então, voltou à carga. Ele "denunciou Thomas por uma ferida maliciosamente infligida". Neste ponto, a história ganha outro indício documental. Essa denúncia está preservada numa série de fólios que se tornaria conhecida como "Apelações à Coroa apresentadas no Condado de Gloucester" (Pleas of the Crown in the County of Gloucester). O texto brevíssimo, que mal preenche uma página dos livros atuais, registra a acusação de "felonia", isto é, de traição cometida contra um senhor a quem se deve lealdade. ${ }^{14}$ George, uma vez mais, foi além. Ele solicitou que a injúria fosse reconhecida pelo tribunal como uma "mutilação". Explorando a força jurídica contida no derramamento do sangue senhorial, ele tentou colocar-se sob o amparo de leis normandas que, reiteradamente retomadas após a conquista de 1066, estipulavam castração e cegueira como punições por atos de mutilação. A demanda foi negada. Talvez porque não fosse condizente com a própria figura do denunciante, talvez porque Thomas negasse peremptoriamente a acusação. Seja como for, a negação predizia um impasse. Os juízes não dispunham do suficiente para se pronunciar - embora tenham reconhecido que Thomas era culpado quanto à ferida infligida. A sentença deveria ser proclamada noutra instância, em outro tribunal. A verdade seria alcançada nas cercanias de Worcester, em um descampado, onde tudo ocorreria sob a benção da Virgem Maria ${ }^{15}$ (MARTINDALE, 2001, p. 116-149; BARTLETT, 2010. 197-212).

A justiça seria obra de um duelo.

\section{Dura Lex, sed Regis}


$\mathrm{Na}$ data determinada, 5 de agosto de 1221, Thomas e George estavam novamente prestes a trocar golpes. Desta vez, o combate não seria travado no cenário poeirento de uma estrada rural, mas sobre um verdejante campo de batalha; o desfecho não ocorreria fora das vistas e longe dos ouvidos, mas sob a atenção cerrada de "juízes e uma multidão de ambos os sexos". Mas, quando assumiram posições, os dois combatentes eram figuras muito diferentes. Avessas, se poderia dizer. Antes traiçoeiro e covarde, George surge em vulto valente, algo cavaleiresco. O tempo todo em pé em meio à multidão, ele se mostrava "confiante em sua força, ágil nas habilidades e pronto para a ação". Thomas, por sua vez, era a aflição em pessoa. O homem outrora moderado e vigoroso se comportava como se profetizasse a derrota. Ele entregava a confiança a Deus, suplicava o socorro de Maria e de São Wulfstan, "chorando copiosamente pelo ocorrido e prometendo emendar-se". Suas existências parecem ter sido recalibradas pela narrativa, como se ajustadas para expressar o desfecho jurídico já alcançado, cristalizado antes da segunda denúncia. Tendo recebido o apoio de uma assembleia de homens livres, George assume porte altivo e imperturbável; tendo sido preso por "violar a paz do rei" e despojado de patrimônio, Thomas decai como criatura alquebrada e culpada. Inscrita nos corpos, cartografada em gestos, a ontologia da lei ${ }^{16}$.

A diferença não abreviou o combate. A multidão aglomerada sobre o descampado testemunhou um duelo renhido. Ambos "infligiram e receberam ferimentos" - assegura a história sem revelar as armas empunhadas. Mas a cada recuo instintivo, toda vez que um passo atrás selava preciosos instantes de trégua tácita, era possível notar que Thomas suportava os piores cortes. Os golpes eram enterrados em sua carne com uma fúria maior, transformando o duelo em prova de resistência. A força do adversário progressivamente amassou os movimentos de Thomas, encurralado por sucessivos ataques. Desferidos em sequência, os golpes já não caíam sobre seu corpo como pancadas e estocadas, mas como uma pressão incessante que lhe vergou o ímpeto de cada músculo. Com braços e pernas queimando em agonia, Thomas suportou as investidas, até que, exaurido, caiu. E quando o chão deteve a queda foi possível notar que o olho direito pendia sobre a bochecha, quase arrancado. Era o fim. Fora derrotado - admitiu. Imediatamente, o vencedor caminhou até ele e arrancou-lhe as roupas de combatente. Thomas "foi deixado seminu sobre o campo". A nudez era um ato jurídico: quando pousaram os olhos sobre ela, os presentes souberam que o "resultado do duelo estava irrevogavelmente declarado"17.

Segundo o costume do reino, o vencido em duelo era condenável à forca. Mas os "juízes mesclaram misericórdia à sentença e declararam-no merecedor da castração". Em seguida, Thomas seria cegado. E a sentença seria aplicada pelos "homens e parentes do vitorioso". A punição ocorreria, portanto, como ato senhorial. Não se tratava de uma reles vingança pessoal, mas da demonstração de prerrogativas aristocráticas. Afinal, não foi propriamente George o agente autorizado a aplicá-la. O executor era sua familia, a rede de dependentes que incluía aliados (seus "homens" ou, como consta em latim, affinibus) e consanguíneos (propinquis, termo traduzido por "parentes"). A evocação do sangue foi, enfim, atendida. A sentença reparava a injúria cometida contra uma posição social, e não um dano individual. As mutilações coletivamente infligidas seriam marcas permanentes da preservação social da diferença, da força crua da hierarquia, fazendo da carne retalhada a prova real do "critério de distinção". E elas seriam algo mais ${ }^{18}$.

As mutilações substituiriam o enforcamento - procedimento ditado pelo "costume do reino". Sua aplicação concretizaria outra certeza, a de que a autoridade dos juízes do rei se sobrepunha legitimamente sobre o costume local. Estamos diante de uma 
estratégia habilidosa. Ao autorizarem que a parentela inteira executasse a sentença, os magistrados criaram um mecanismo que implicaria uma parcela da aristocracia no estabelecimento de uma jurisdição dotada de certa autonomia em relação às práticas regionais de gestão da justiça. No instante em que os "homens e parentes do vitorioso" abrissem fendas no corpo do derrotado, sua posição social seria atrelada à obediência ao que havia sido anunciado em nome do rei. A sentença era um mecanismo de fortalecimento da dominação senhorial e simultaneamente de criação de uma hegemonia legal da corte. Melhor dizendo: era uma forma de fortalecer a dominação senhorial como hegemonia legal da corte. Portanto, esse direito que nos chega cruel e desumano cumpria o imprescindível papel de normalizar um novo capítulo da Common Law. A caracterização da felonia - traição contra um senhor - como o crime que evocava a punição por meio de mutilações tornava a reparação durável. Em épocas ancestrais, a condenação por tão grave ofensa resultava em uma compensação pontual, como pagamento em dinheiro ou enforcamento, o que tornava a sentença evento efêmero, um acontecimento, fragmento de tempo. Agora, em razão dos procedimentos da jurisdição régia e do apoio senhorial, a punição se esticava para além do ato de punir, era convertida em marca permanente, num estigma que seria visto respirando e caminhando por anos ou mesmo por décadas. As mutilações rotinizavam a pacificação pretendida pela corte (VAN EICKELS, 2004, p. 588-602; BELLAMY, 1998, p. 19-56; MARTINDALE, 2001, p. 116-149; BRAND, 2001, p. 150-159; VALE, 2000, p. 159181).

A aplicação da sentença foi uma cena aterradora. Thomas teve um olho removido de uma só vez, através de um golpe sedento de dor. O outro, muito ferido, "ofereceu maior resistência para ser arrancado e o foi somente com grande dificuldade e angústia para o homem sofredor". George e os seus se revezaram no cabo da lâmina, perfurado a cavidade ocular "duas ou três vezes", enterrando o gume "em direção ao fundo da cabeça". Àquela altura já não era possível distinguir "a luxúria por punir [...] do amor à justiça". Movidos pelo desejo de extinguir a vida de Thomas, os "executores agiram com crueldade e, com um grande golpe, deceparam as pupilas e os nervos que, escavados, pendiam sobre a face, jogando-os ao chão". Em seguida, arrancaram os testículos e os jogaram ainda mais longe, "para que alguns rapazes os chutassem uns para os outros entre garotas". Quando já não poderiam infligir mais dor sem extrapolar os termos da sentença, foram embora. Thomas foi abandonado, semivivo. O pobrediabo chafurdava "no próprio sangue, que escorria de suas feridas em tal fluxo que, mal respirando, se poderia crer que chegara a exalar o último suspiro". Pela primeira vez, vemos suas feridas verterem sangue ${ }^{19}$.

Sangue que contaria a história de outro modo.

\section{Distinguir os sangues}

Thomas foi ferido muitas vezes, mas seu sangue foi visível apenas no fim, quando tudo estava terminado, quando não havia mais golpes, fugas ou desagravos. Era, portanto, um sangue já derramado, vertido, empoçado. Diferente do de George, narrado sempre em movimento. Primeiro, sobre a pele, escorrendo em linhas visíveis sobre o braço; segundo, sobre o espaço, exibido sempre em deslocamento, fosse na fuga para casa ou ao se dirigir aos poderes públicos. Apresentado como líquido que já não tem 
lugar no corpo, o sangue de Thomas possui outras conotações. Como no caso de George, é um elemento figurativo. Mas uma figuração distinta, que não evoca a distinção hierárquica porque projeta a mente noutra direção, rumo ao imutável, à inefabilidade do sagrado. Como? Talvez seja difícil notar na primeira leitura. Talvez o que está sendo sugerido nestas linhas possa soar como um excesso de interpretação. Que seja. As implicações da afirmação justificam o risco: o sangue de Thomas evoca e provoca um laço de natureza espiritual, é o marcador de outro modelo de governo comunitário - diferente do já visto, o da hierarquia senhorial. Modelo cuja singularidade era fundada biblicamente. O sangue de Thomas evoca o próprio Cristo. Observe-se.

Há uma similitude sutil e desconcertantemente precisa entre a punição a Thomas e a Paixão do Cristo: o instante em que o sangramento emerge na narrativa. Para entendêla melhor é preciso ter em mente um dado notado com perspicácia por Caroline Bynum. Eis sua constatação: "os evangelhos sinóticos mencionam sangramento literal apenas em conexão com o suor de Cristo no Monte das Oliveiras, e mesmo essa referência [...] está ausente em alguns manuscritos antigos". A cena é anterior ao beijo de Judas e à captura. O Jesus que sangra, portanto, transpira aflições, ajoelhado, suplicante - mas, livre. Ainda não está em poder dos capitães do templo, tampouco sob julgamento, metido em grilhões. Quando isso ocorrer, as grandes gotas vermelhas que escorriam de sua fronte já não serão mencionadas. Não se falará delas. Portanto, apesar da flagelação e das dores excruciantes do calvário, as Escrituras não mencionam sangue na crucificação. "Somente o evangelho de João", prossegue Bynum, "menciona a perfuração do flanco de Cristo com uma lança e o subsequente escoamento de sangue e água; e João deixa claro que a ferida ocorreu tão somente quando Jesus já estava morto". A correspondência entre os casos não é perfeita, pois Thomas não estava morto. Uma diferença nada desprezível. Pode-se dizer que ela condensa a incomensurável distância que separa o humano e o divino, já que o sangue de Cristo é o único que conserva a vida mesmo após escorrer sobre a pele em lividez azulada, escoando de um corpo onde a morte fez morada. Não obstante a diferença, a similitude é notável e consistente. Como no relato joanino, o sangue de Thomas é mencionado em um momento específico e muito significativo. Sua aparição textual não á aleatória ou furtiva. É, sim, uma poderosa figura retórica. É a marca de que Thomas, condenado e sentenciado, arquejando a instantes de entregar o último suspiro, estava mais próximo dos portões do reino dos céus; de que ele era o protagonista de uma segunda transição, de uma passagem do pertencimento terreno para o espiritual. Desse ponto em diante, Thomas se torna uma alegoria da comunidade governada pela Igreja. (BYNUM, 2007, p. 1; FAHNESTOCK, 1999)

Tomados por misericórdia - prossegue a história - alguns homens o ergueram do chão ainda aquecido pelo calor do sangue. "Para que não fosse deixado para ser devorado por cães", eles o ampararam pelos braços, colocaram num cesto e o levaram à enfermaria do mosteiro de São Wulfstan. Os irmãos responsáveis pela casa se recusaram a acolhê-lo, bradando que um condenado era "uma desgraça, indigno de seus cuidados". Thomas foi deixado do lado de fora, despejado miseravelmente contra um muro. Ele mal se movia. Todos os músculos estavam rendidos a "dores, que só poderiam ser expressas por aquele que as sofre". Macerado pelas feridas, "tomado por [...] sofrimento, ódios e confusão, ele foi banido do mundo como um ser vil, desprezado e detestado até mesmo pelos mais caros a ele". Mas, porque havia sido desgraçadamente abandonado, aquele corpo se convertera em território do divino. Sob as misérias que varavam a carne, uma mudança sagrada era operada, uma transformação tão sublime 
quanto invisível para olhos pecadores. Caído em "seu sangue" (suo sanguine), Thomas estava mais próximo do Salvador: "oh, Jesus, a ti o pobre homem é entregue, e tu auxiliarás o órfão que o pai mundano expulsou". Aqui, atenção redobrada aos detalhes! O vocabulário utilizado é singular e sugere uma relação que ocupará o núcleo da narrativa. Ele faz da proximidade com o espiritual uma maneira de criar laços que superam o parentesco terreno: "tu auxiliarás o órfão que o pai mundano expulsou". Laços que superam e se impõem como realidade. Não é fácil descobrir a quem a narrativa se refere por "pai mundano". Por tudo que foi visto, não parece coerente que se trate de Estmar, figura de uma severidade paterna exemplar - "piedosa", lembremos - e que partilhara da desgraça do filho. Talvez seja uma alusão ao rei, cuja autoridade falhou com Thomas no instante em que os juízes se pronunciaram pelo "odioso duelo", deixando um homem bom desamparado de justiça virtuosa. Seja como for, em qualquer dos casos, a narrativa comporta a mensagem de que o parentesco espiritual prevalece sobre o terreno, seja ele consanguíneo ou não ${ }^{20}$.

Mas, prevalece de fato? - talvez um leitor esteja perguntando. Afinal, até aqui, a vida de Thomas é uma marcha irreversível para a degradação pública, um conto de ruína e decadência. E esse leitor teria razão. A pergunta vai ao âmago do argumento. Onde está a dimensão triunfal do espiritual quando ele surge nas margens na história? Como se pode falar em "prevalecer" quando o enlace espiritual ocorre nas sombras, em meio ao repúdio e ao abandono? A resposta não é dúbia ou hesitante. Sim, prevalece. Sendo mais preciso: sim, prevalecerá. Pois está por vir. E ocorrerá de modo contundente, inigualável, graças à natureza maravilhosa do desfecho preparado para a narrativa. Prestes a ser encerrada, a história anuncia o triunfo do parentesco espiritual como um milagre. Voltemos à trama.

$\mathrm{Na}$ enfermaria havia uma mulher, Isabel. "Dedicada particularmente ao serviço aos pobres", ela apiedou-se do homem coberto por feridas. Isabel infringiu as proibições dos irmãos e clandestinamente cuidou de Thomas. Dia após dia, "ela limpou os olhos vazios", aplicou curativos aos cortes, "tranquilizando e curando segundo o exemplo do Samaritano". Oito dias passaram. Quando o nono estava prestes a se recolher noutro lado do horizonte, o paciente se dirigiu à igreja para acompanhar a celebração das vésperas à Virgem Maria. Com o peito inundado pela "mais fervorosa devoção", ele acompanhou a solenidade com uma entrega física plena. Rezou com afinco, multiplicou as súplicas vezes sem conta até que, uma vez mais, foi arrebatado para os confins da existência, a fronteira entre o céu e a terra. Thomas caiu em transe, em uma "sonolência tão superficial que não sabia se estava acordado ou dormindo". Cego, com as órbitas ocas ainda sob os cuidados diários de Isabel, ele se deu conta de que percebia o espaço ao seu redor e notou que toda a casa parecia brilhar, cintilando uma luminosidade tão ofuscante quanto um lampejo de um relâmpago. Banhada em luz, surgiu a Virgem Maria, acompanhada de São Wulfstan. Eles caminhavam em sua direção. Ela, adornada "em mitra", ele, "completamente vestido em trajes pontificais". Ao se aproximarem da sua cama, o abençoaram e seguiram adiante, continuando sua jornada pela eternidade. Ao despertar, Thomas gritou: "Santa Maria e São Wulfstan estavam presentes"! ${ }^{21}$

Passou por louco. Seu comportamento foi considerado de "alguém desequilibrado pela ferocidade da dor". Intimidado, desmentiu-se. Mas à medida que ele passava os dias desdizendo a "visão gloriosa", sentia que as pálpebras flácidas e cada um dos ferimentos recebidos no duelo "começavam a coçar". A coçar incessantemente. A coceira formigava com tal intensidade que algo parecia revirar dentro dele. Quando já não conseguia conter a mãos, chamou Isabel e pediu que ela lhe lavasse os olhos e 
ferimentos. Com "obediência dedicada", ela começou a preparar a água. Mas a comichão tornou a espera impossível. Impaciente, agitado, Thomas se adiantou aos procedimentos. Ele "se virou para a parede, colocou os dedos sobre as pálpebras e as puxou para trás". "E eis que, para sua surpresa e espanto, ele observou uma luz entrando pela porta [...]. Virando-se em direção à rua, ele viu, claramente, pessoas indo e chegando". Os olhos haviam retornado às cavidades! Não estavam plenamente formados, eram minúsculos, como duas pequenas ameixas. Contudo, "cresceriam de um dia para o outro até atingir tamanho adequado". 22

O pobre homem encontrou o cuidado em uma medicina suprema, já que "todas as diversas feridas que ele sofrera no duelo receberam a cura no mesmo momento, como se tivessem [recebido os cuidados do] mesmo médico"23. Note-se: "todas as feridas". Isso significa que os órgãos genitais também foram restabelecidos, tendo crescido novamente. Façanha médica inigualável, o milagre era também o sinal de que o caso de Thomas fora reconsiderado em uma jurisdição superior à do rei e sua corte. Na medida em que os olhos e as genitais do condenado cresceram, a justiça terrena atrofiou, encolhendo de tamanho até desaparecer. Com as mutilações revertidas pela cura milagrosa, a sentença dos juízes do rei estava desfeita.

A Common Law estava sujeita a não durar.

\section{Governar a comunidade}

Talvez justamente por essas implicações, por ser uma anulação da sentença ditada em nome do rei, a notícia do milagre causou alvoroço. O falatório foi crescente. Logo as ruas de Worcester foram tomadas por comoção, que chegava a todos os ouvidos, inclusive aos de forasteiros como Bento, bispo de Rochester. Cruzando a cidade em peregrinação, ele se viu enredado no disse-me-disse sobre a maravilha assombrosa. Cético, com o juízo amotinado feito apóstolo Tomé, Bento montou no cavalo e esporeou até a enfermaria do mosteiro. Uma vez lá, ele convocou o capelão e o instruiu: vá ter com esse Thomas sobre quem tanto se fala e diga-lhe que recebeste ordens para "apalpar seus órgãos masculinos". Sendo monge, como um subalterno hierárquico, o capelão não pôde deixar de obedecer. Minutos depois, ele estava de volta com a notícia. De joelhos perante o tal homem, ele "moveu a mão na direção da virilha e sentiu [os testículos]". O bispo prontamente caiu em prantos, com sua mente rendida à certeza: o caso "era exatamente como fora contado". Chorando copiosamente, o eclesiástico caminhou até o quarto de Thomas e suplicou para repetir o gesto do enviado, justificando-se: "eu também os toco, não para satisfazer minha incredulidade, mas para que eu me torne testemunha verdadeira e fiel de um milagre tão grande". E, "tendo feito isso" - conclui a história - "ele glorificou a Deus, montou no seu cavalo e seguiu seu caminho em alegria". Sacolejando sobre a montaria episcopal, a boa nova cruzou o limite da cidade e ganhou o mundo ${ }^{24}$.

Pode ser que olhos educados em uma moralidade burguesa enxerguem no episódio apenas valor pitoresco; prato cheio para a psicanálise e uma bandeja de migalhas para um estudo histórico. Mas não é bem assim. A cena do toque possui um protagonista especial. Bento é uma figura duplamente pública: é bispo e peregrino. Sua glorificação do milagre é, portanto, um testemunho público, ou, nos termos da narrativa, o "testemunho autêntico de um dos homens veneráveis (maiorum)" ${ }^{25}$. O eclesiástico de 
espírito cético é a instância que transforma a ocorrência pessoal em verdade coletiva, pronta para ser anunciada ao mundo. Lembra algo? Provavelmente, sim. Ao personificar a autoridade dos "maiores", dos veneráveis, Bento desempenha um paralelismo relevante: o bispo é para o milagre de Thomas aquilo que a "assembleia inteira de homens" foi para a ferida de George. E assim o texto desenha um contraponto, ou melhor, inscreve um contrapeso ideológico na trama: o conselho de laicos e o clero atuam como instâncias divergentes. $O$ primeiro concretizou a legalidade de uma acusação e pôs em movimento a exclusão do acusado; já o segundo consumou a anulação de uma sentença e levou a termo o restabelecimento do condenado. Há aqui uma mensagem social de enorme relevância. O ensinamento de que a Igreja é a instância final de reordenamento da comunidade cristã, que o clero é o agente que conduz até a superação da justiça imperfeita e da paz corrompida. Como essas duas virtudes tortas haviam sido obra da realeza, há mais implicações espremidas nas entrelinhas. É preciso, portanto, pensar com vagar, decompondo as camadas de ideias. O passo a passo bem vale um novo parágrafo.

Eis, então, a mensagem: Igreja e Realeza não coincidem nas maneiras de conduzir a comunidade cristã; mas as divergências não justificam contestação ou sedição; o clero não deve interromper o curso da justiça e da paz arquitetadas pelos reis; por mais viciosas e odiosas que possam ser, elas são legítimas; os reis, porém, passam e as decisões tomadas em seu nome são tão transitórias quanto suas vidas; na latitude das gerações, é a ação dos eclesiásticos que prevalece, corrigindo erros e maldades zelosamente suportados - e eles devem ser suportados! - pela comunidade dos fiéis.

Aqui, façamos ponto. Antes de prosseguir é preciso cogitar uma dúvida: acaso não se está aqui confundindo "eclesiástico" e "sagrado"? Afinal, não são sinônimos. E o relato é incisivo: a sentença imposta pela justiça régio-senhorial foi anulada "milagrosamente". Forças espirituais desfizeram mutilações, curando "todas as feridas". Não seria, portanto, mais preciso dizer que é a ação do sagrado que prevalece? A resposta é não. Expliquemos. Sem dúvida, o desfecho desta história é uma proeza metafísica, cujas causas e agentes são situados pela narrativa além da condição humana. Mas note-se que o sagrado ocorre de modo específico, como um enredo movido por elementos especificamente eclesiásticos. O estado de sonolência no qual Thomas foi "colocado por Deus" e que propiciou a visão luminosa de Maria e Wulfstan é liturgicamente induzido. $\mathrm{O}$ estado físico que possibilitou sua participação no sagrado foi causado por orações exaustivamente proferidas na "igreja catedral" durante a "vigília pela assunção da santa Virgem". A devoção daquele homem retalhado foi uma prática iniciatória emoldurada por um quadro espaço-temporal singular: lugar e tempo eclesiásticos. Maria e Wulfstan andaram na direção de Thomas portando insígnias. Ela, uma mitra; ele, trajes pontificais. O "fulgor resplandecente" irradiado por suas silhuetas celestiais reluzia símbolos da autoridade episcopal terrena. Por fim, e talvez ainda mais importante, convém reparar que o milagre careceu de respaldo social. O relato mantém a ocorrência sagrada como fenômeno incompleto, como uma história inacabada até o aparecimento do bispo de Rochester. Somente com o testemunho dele, Bento, selou-se a autenticidade de "tão grande milagre"; o ceticismo e a desconfiança perderam o verbo de uma vez por todas. Isabel, o monge capelão e o próprio Thomas: nenhum deles bastou para dotar o milagre de força suficiente para conformar as atitudes e as reações coletivas. Como realidade social, o milagre foi concluído somente quando um bispo foi persuadido - não quando os órgãos foram maravilhosamente devolvidos ao mutilado. Da indução à autenticação, o sagrado consagrou a superioridade do espaço, do 
calendário, das insígnias e da voz dos eclesiásticos. Podemos, agora, reatar a redação do parágrafo anterior.

Em termos políticos, a mensagem veiculada por essa história milagrosa é a de um equilíbrio tenso, de um entrelaçamento entre o conformismo e a rivalidade. Esta narrativa faz Igreja e Realeza coexistirem publicamente na Inglaterra do século XIII, mas como vozes que se alternam no governo da comunidade cristã. Sendo que tal caracterização não parece condizer com a ideia consagrada na historiografia - e ainda influente nos dias de hoje - de que os dois poderes eram concebidos como naturezas distintas: um, espiritual, o outro, secular. Não. Ambos são apresentados como instituições efetivamente temporais. Como dois artífices rivais, em permanente disputa pela oportunidade de modelar o ritmo com que as coisas mudam ou acontecem no interior da comunidade. Cada qual o detentor de uma maneira própria para esculpir a vida neste mundo.

Sangue é um marcador interno da vivência desse equilíbrio. Considerá-lo mero componente cenográfico, simples adorno dramático, é ignorar um indício valioso quiçá, insubstituível - sobre as formas de pensar politicamente na Idade Média. Por tudo que foi lido até aqui, o sangue pode ser considerado parte de um problema central para a vida em sociedade: a significação da ordem. Enquanto o sangue de George é apresentado como figura da distinção, o de Thomas é uma forma de purificação: é o sangue verdadeiramente cristão, completamente bom porque inteiramente vulnerável. $\mathrm{O}$ fluxo do primeiro sangue é um Principium Individuationis, um "Critério de Distinção"; já o do segundo, um "Index Reformationis", um "Signo de Restauração". O líquido que vemos banhar o chão ao redor de Thomas não evoca e provoca a justiça, mas a durabilidade. Ele é o elemento que ajuda a fixar uma dívida de tempo: magnatas e juízes têm a justiça, eles a modulam e a aplicam como bem entendem; mas, se o fizerem à revelia do bem e das virtudes, sua realização já é presa do tempo e será devorada. Quando isso ocorrer, a comunidade persistirá, pois será resgatada pela Igreja "da insuportável abdução do medo da morte" - como notou Roberto Espósito ao reconhecer que a noção cristã de communitas ("comunidade") lança desafios permanentes à escatologia e à própria metafísica (ESPOSITO, 2010, p. 12).

Essa história miraculosa, iniciada com o ingresso de um jovem na vida econômica, tem no sangue uma sinédoque. Um elemento que substituiu referências explícitas a outros numerosos temas. Precisamente por ser forma de expressão de diversos aspectos da vida, ele faz e desfaz o familiar, o social, o jurídico, o econômico e o político (ANIDJAR, 2016, p. 258). "Sangue" é um nome com o qual cristãos medievais mensuravam sua existência coletiva.

\section{Referências:}

\section{Documentos Medievais:}

Annales de Wigornia. In: LUARD, Henry Richards (Ed.). Annales Monastici. Londres: Longmans et alii, 1869, vol. 4. 
GAROFALO, Salvatore (Ed.) - Biblia sacra Vulgatae editionis Sixti V Pont. Max. iussu recognita et Clementis VIII auctoritate edita. Editio emendatissima apparatu critico instructa, cura et studio Monachorum Abbatiae Pontificiae Sancti Hieronymi in Urbe Ordinis Sancti Benedicti. Turim: Marietti, 1965.

MAITLAND, Frederic William (Ed.). Pleas of the Crown in the County of Gloucester. Londres: Macmillan \& Co., 1884.

Vita Wulfstani. In: DARLINGTON, Reginald R. (Ed.). The Vita Wulfstani of William of Malmesbury. Londres: Camden Society, n.s. xl, 1928, cap. 16, p. 168-175.

\section{Bibliografia:}

ANIDJAR, Gil. Blood. A Critique of Christianity. Nova York: Columbia University Press, 2016

ARMSTRONG, Karen. Campos de Sangue: religião e a história da violência. São Paulo: Companhia das Letras, 2016.

AUERBACH, Erich. Mimesis: a representação da realidade na literatura Ocidental. São Paulo: Perspectiva, 2001. p.1-20

BALMACEDA, Catalina. Virtus Romana: Politics and Morality in the Roman Historians. Chapel Hill: The University of North Caroline Press, 2017.

BARTLETT, Robert. Feud, Violence and Practice. Farnham: Ashgate, 2010.

BELlAMY, John G. The Criminal Trial in Late Medieval England: Felony before the Courts from Edward I to the 16th Century. Toronto: University of Toronto Press, 1998.

BILLER, Peter; MINNIS, A.J. (Ed.). Handling Sin: confession in the Middle Ages. York: York University Press, 1998.

BRADBuRne, James (Ed.). Blood: Art, Power, Politics, and Pathology. Munique: Prestel, 2001.

BRAND, Paul. Local custom in the early common law. In: STAFFORD, Paul; NELSON, Janet L.; MARTINDALE, Jane (Ed.). Law, laity and solidarities: Essays in honour of Susan Reynolds. Manchester: Manchester University Press, 2001, p. 150-159.

BRITNELL, Robert H. The Commercialisation of English Society (1000-1500). Cambridge: Cambridge University Press, 1993.

BROWN, Peter. The Ransom of the Soul: Afterlife and Wealth in Early Western Christianity. Cambridge MA: The Harvard University Press, 2015. 
BYNUM, Caroline Walker. Wonderful Blood: Theology and Practice in Late Medieval Northern Germany and Beyond. Philadelphia: University of Pennsylvania Press, 2007.

CHURCH, Stephen. King John: England, Magna Carta and the Making of a Tyrant. Londres: Pan Books, 2015.

CHURCH, Stephen. King John: England, Magna Carta and the Making of a Tyrant. Oxford: MacMillan, 2015.

DAMIEN-GRINT, Peter, 2019 Worcester, Senatus of [called Senatus Bravonius]. Oxford Dictionary of National Biography [Online]. Acessado online, em 22/12/2019, através do link: http://www.oxforddnb.com/view/article/25083.

DE YONG, Mayke. Transformation of Penance. In: THEUWS, Frans; NELSON, Janet (Ed.). Rituals of Power: from Late Antiquity to Early Middle Ages. Leiden: Brill, 2000, p. 185-225.

DOBB, Maurice. Studies in the Development of Capitalism. Londres: Routledge, 1946.

DUBY, Georges. A Idade Média na França: de Hugo Capeto a Joana D'Arc. Rio de Janeiro: Zahar Editor, 1992.

ERIKSEN, Christoffer Basse. "Circulation of Blood and Money in Leviathan - Hobbes on the Economy of the Body". In: BEK-THOMSEN, Jakob; CHRISTIANSEN, Christian Olaf; GAARSMAND JACOBSEN, Stefan; THORUP, Mikkel (Ed.). History of Economic Rationalities: Economic Reasoning as Knowledge and Practice Authority. Dordrecht: Springer, 2017, p. 31-41.

ESPOSITO, Roberto. Communitas: the origin and destiny of Community. Stanford: Stanford University Press, 2010.

FAHNESTOCK, Jeanne. Rhetorical Figures in Science. Oxford: Oxford University Press, 1999.

GALEANO, Eduardo. As veias abertas da América Latina. Rio de Janeiro: Paz e Terra, 1979.

HARDY, Thomas Duffus (Ed.). Descriptive Catalogue of Materials Relating to the History of Great Britain and Ireland to the end of the reign of Henry VIII. Cambridge: Cambridge University Press, 2012, vol. 2.

HATCHER, John; BAILEY, Mark. Modelling the Middle Ages. The history and theory of England's Economic Development. Cambridge: Cambridge University Press, 2001.

HUDSON, John. The Formation of English Common Law: Law and Society in England from King Alfred to Magna Carta. New York: Routledge, 2018. 
HYAMS, Paul R. Rancor and Reconciliation in Medieval England. Ithaca e Londres: Cornell University Press, 2003.

HYAMS, Paul R. Tales from the medieval courtroom: the fall and rise of Thomas of Elderfield. Humanities Working Paper, n. 107, 1985. Acesso online em 22/12/2019, atavés do link: https://authors.library.caltech.edu/18859/1/HumsWP0107.pdf.

JOHNSON, Jerah. The Money=Blood Metaphor, 1300-1800. The Journal of Finance, vol. 21, n. 1, 1966, p. 119-122.

LE GOFF, Jacques. A Bolsa e a Vida: economia e religião na Idade Média. São Paulo: Brasiliense, 2004.

LITTLE, Lester K. Religious Poverty and the Profit Economy in Medieval Europe. Ithaca: Cornell University Press, 1983.

LOPEZ, Roberto. The Commercial Revolution of the Middle Ages, 950-1350. Cambridge: Cambridge University Press, 1976.

MALÝ, Jan. The Invasion of Prince Louis of France to England, 1216-1217. Prague Papers on the History of International Relations, Feb. 2016, p. 7-20. Acesso em 22/12/ 2019, através do link: http://cejsh.icm.edu.pl/cejsh/element/bwmeta1.element.desklight-5c6486c6-8fe1$\underline{4 \mathrm{e} 22-\mathrm{b} 407-\mathrm{e} 755 \mathrm{c} 33 \mathrm{~b} 80 \mathrm{ea}}$

MARTINDALE, Janes. Between Law and Politics: The Judicial Duel under the Angevin Kings. In: STAFFORD, Paul; NELSON, Janet L.; MARTINDALE, Jane (Ed.). Law, laity and solidarities: Essays in honour of Susan Reynolds. Manchester: Manchester University Press, 2001, p. 116-149.

MAY, James. Trials of Character: The Eloquence of Ciceronian Ethos. Chapel Hill: The University of North Caroline Press, 1988.

McCALL, Tom. "Momentary Violence". In: FERRIS, David (Ed.). Walter Benjamin: Theoretical Questions. Stanford University Press, 1996, p. 185-208.

MEENS, Rob. Penance in Medieval Europe, 600-1200. Cambridge: Cambridge University Press, 2014.

MELL, Julie Lee. Religion and Economy in Pre-Modern Europe: The Medieval Commercial Revolution and the Jews. (Tese de Doutorado), Univesity of North Carolina, 2007.

MEYER, Melissa. Thicker than water: the origins of blood as symbol and ritual. Nova York e Londres: Routledge, 2005.

NAISMITH, Rory. "Turpe Lucrum? Wealth, Money and Coinage in the Millennial Church". In: GASPER, Giles; GULLBEKK, Svein (Ed.). Money and the Church 
in Medieval Europe, 1000-1200: Practice, Morality and Thought. Nova York: Routledge, 2015, p. 17-38.

POSTAN, Michael. Mediaeval Capitalism. The Economic History Review, vol. 4, n. 2, 1933, p. 212-277.

PRODI, Paolo. Settimo non Rubare. Furto e mercato nella storia dell'Occidente. Bolonha: Il Mulino, 2009.

ROUX, Jean-Paul. Le Sang. Mythes, symbols et réalité. Paris: Fayard, 1988.

RUST, Leandro Duarte. Bispos Guerreiros: violência e fé antes das cruzadas. Petrópolis: Vozes, 2018.

SEEL, Graham E. King John: an underrated king. Londres: Anthem Press, 2012.

SENNET, Richard. Carne e Pedra: o corpo e a cidade na Civilização Ocidental. Rio de Janeiro: Record, 2003.

SOMBART, Werner. Der Moderne Kapitalismus. Berlim: Duncker \& Humblot, 1902.

STRICKLAND, Matthew. Against the Lord's anointed: aspects of warfare and baronial rebellion in England and Normandy, 1075-1265. In: GARNETT, George; HUDSON, John (Ed.). Law and Government in Medieval England and Normandy: Essays in honor of Sir James Holt. Cambridge: Cambrdige University Press, 1994, p. 56-79.

TODESCHINI, Giacomo. I Mercanti e il Tempio. La società cristiana e il circolo virtuoso della ricchezza fra Medioevo ed età moderna. Bolonha: Il Mulino, 2002.

VALE, Malcolm. Aristocratic Violence: Trial by Battle in the Later Middle Ages. In: KAEUPER, Richard (Ed.). Violence in Medieval Society. Woodbridge: The Boydell Press, 2000, p. 159-181

VAN EICKELS, Klaus. Gendered Violence: Castration and Blinding as Punishment for Treason in Normandy and Anglo-Norman England. Gender \& History, vol.16, n.3, 2004, p. 588-602.

WEST, Francis. Justiceship England 1066-1232. Cambridge: Cambridge University Press, 1966.

WHEATHLEY, Edward. Stumbling Blocks Before the Blind: medieval constructions of a disability. Ann Arbor: The University of Michigan Press, 2010. 


\begin{abstract}
${ }^{1}$ Docente da UnB e Pesquisador do Programa de Estudos Medievais (PEM-UnB). Pós-Doutorado pela Universidade de São Paulo e pela Catholic University of America, em Washington (2016).

${ }^{2}$ As passagens documentais citadas ao longo do parágrafo foram retiradas deste fragmento: Fuit in comitatu Gloucestrie in uilla de Trinleia quidam iuuenis Thomas nomine filius Estmeri de Nordweia hominis quidem libere conditionis; set substantie tenuis. Hunc cum sibi uix sufficeret; pater iam adultum a se pia seueritate propulsauit, ut alicui probo uiro deseruiens, sue consuleret necessitati; et addiscende intenderet curialitati. (Vita Wulfstani, 1928, p. 168). Todas as traduções para o português referentes a passagens da Vita Wulfstani são de minha autoria.

${ }^{3}$ As citações documentais do parágrafo foram retiradas do trecho a seguir: Nam statim admissus; adhesit cuidam de aulicis, et gratiam familie sedulus sibi minister adquisiuit. Unde et in multis sibi lucrifaciens; in brevi multa congessit, tempore messis procederet uberius collecturus. (Vita Wulfstani, 1928, p. 168)

${ }^{4}$ Para as citações documentais realizadas ao longo do parágrafo: Post aliquota annos sibi in pecunie uenationibus decursos natale solum adiit, patrem uisurus et patriam. Ibique aliquandiu commorans, ex perquisitis secularium more negociis; diuitias sibi sollicitus asciuit. [...] et ab illo sepius pecuniam mutuata; [...]. (Vita Wulfstani, 1928, p. 168-169)
\end{abstract}

${ }^{5}$ [...] ex perquisitis secularium more negociis; diuitias sibi sollicitus asciuit. (Vita Wulfstani, 1928, p. 168-169). Na tradução, optei pelo singular para secularium. O critério foi meramente estilístico: supus que "à maneira de quem vive nos séculos" pudesse sugerir um marcador cronológico - ou mesmo uma associação à longa duração - ao invés de sociológico, como acredito ser o caso. "Século" é aqui, primordialmente, um "lugar no mundo" e não uma "medida de tempo" - embora os dois significados sejam indissociáveis.

${ }^{6} \mathrm{O}$ texto latino para a citação documental realizada neste parágrafo encontra-se transcrito na nota 2.

${ }^{7}$ As diferentes citações documentais realizadas ao longo do parágrafo foram retiradas deste fragmento: Quod uidens domina sua uxor scilicet Roberti de Northweia, et ab illo sepius pecuniam mutuata; in ulteriorem adulterii familiaritatem illam allexit, et per biennium ueneris tenuit laqueis irretitum. Qui tandem dei gratia preueniente compunctus; ostendit se sacerdoti. Cuius salubri fretus consilio; digne satisfecit pro commisso. Nec postea licet multum a dicta domina sua sollicitatus, et post obitum uiri sui ad nupcias prouocatus; deo se protegente recidiuauit. Immo post completam satisfactionem iniunctam iteratis uicibus usque quater a diversis sacerdotibus confessus, nouam uoluntarius subiit satisfactionem; et plene compleuit. (Vita Wulfstani, 1928, p. 169) O que consta no texto é "primeiro completou a penitência imposta a ele e, em seguida, confessou-se a cerca de quatro outros sacerdotes". Com tentei pontuar no texto através da expressão "conselho clerical", minha ênfase argumentativa recai sobre a confissão - é ela que sugiro ter ocorrido cinco vezes. Postulo que o cumprimento da penitência tenha implicado a realização da confissão conforme a tradição normativa (MEENS, 2014; BILLER, MINNIS, 1998; DE YONG, 2000, p. 185-225).

${ }^{8}$ Para as citações documentais do parágrafo: Predicta uero ueteris Eue filia dolens se contemptam et erubescens repulsam; mortales aduersus eum concepit inimicitias, ad horam more muliebri dissimulans; set iniuriarum suarum ultionem in tempus oportunum suspendens. Que diuturne uiduitatis pertesa, nupsit cuidam Georgio; astuto nimium et uersipellis uiro. (Vita Wulfstani, 1928, p. 169)

${ }^{9}$ As citações documentais ao longo do parágrafo derivam de: Ad cuius cum peruenisset noticiam sponsam suam cum dicto Thoma sub priore uiro fuisse adulteratam; suspitione torquebatur, et zelo succensus maritali; memoratum Thomam odio persequebatur inexorabili. Quadam igitur die cum ad ceruisiam uenalem conuenissent, et sobrietatis metas egressi ad sua redirent; [...]. (Vita Wulfstani, 1928, p. 169).

${ }^{10}$ Todo o parágrafo baseia nesta passagem: Georgius Thomam methodo ductus preuenit, et obuius ei cum baculo magno illum nichil tale suspicatum percussit in capite; peiora comminatus. Thomas autem preter merita conquerens se percussum, modeste satis illum monuit; ut si ceruisia impellente id fecisset, hac uice contentus indempnis abiret. Si uero super dolorem uulneris sui adderet; non impune transiret. Georgius autem cuius ira non deferbuerat, illum super humerum sinistrum ictu repetito percussit; sicut malitiam non deponens. Thomas bis percussus excanduit; timensque ne si uim ui repelleret mortis periculum incurreret; securim super humeralem quam gestabat leuauit, ut Georgium feriret. Set casu fortuito ferrum securis ulterius quam proposuerat transiecit. Humerumque Georgii manubrio tantum sine lesione percussit. Set securim retrahendo cum posteriori cuspide brachium Georgii modicissime uulnerauit; usque ad sanguinis profluxum tamen. Transiliensque seprem scansilem qualis fieri solet fieri inter uiam et semitam ad tutandas segetes; iter suum accelerauit. (Vita Wulfstani, 1928, p. 169)

${ }^{11}$ As citações documentais do parágrafo foram retiradas da seguinte passagem: Georgius autem omnibus qui pretergrediuntur uiam de sanguinis sui effusione conquerens et auctorem uulneris diffamans; rem aliter quam gesta fuerat enarrabat, se quidem innocenter uulneratum asserens; Thomam autem regie pacis uiolatorem declamans. [...] domum suam a qua non longe distabat festinans repetit, ibique 
cornuum mugitu uiciniam in fugitiuum concitauit; mentiens Thomam sine respectu regie pacis domum suam violenter inuasisse, et catalla sua tanquam predonem nequiter asportasse; sic domum suam defensanti mortiferum uulnus inflixisse. (Vita Wulfstani, 1928, p. 169-170)

${ }^{12}$ Affuit inter alios ad cornitium aduentantes Estmerus pater Thome horum penitus ignarus, filio suo [...]. (Vita Wulfstani, 1928, p. 170).

${ }^{13}$ As duas citações documentais realizadas nas primeiras linhas deste parágrafo se referem a: Insurgunt igitur in Estmerum omnis illa congregatio uirorum tanquam in huius rei fauctorem et conscium, lorisque fortius alligatum; Gloucestriam ducunt uicecomitique tradunt, tenebroso carcere recludendum. Set tandem fideiussoribus datis, et exhausto marsupio; dimittitur. (Vita Wulfstani, 1928, p. 170)

${ }^{14}$ Embora a felonia (felony) possa ser encontrada em diferentes contextos da história legal inglesa como o nome reservado para crimes capitais, como assassinato, roubo, estupro e até mesmo incêndio, aqui, situo a significação do termo como traição ou violação de fé a um senhor a partir da redação latina - que é felonia, como se pode ver na nota a seguir. (Ver ainda: BELLAMY, 1998, p. 13-16, 78-86, 188-192).

${ }^{15}$ Os aspectos destacados ao longo parágrafo quanto ao registro documental nas Apelações foram retirados das seguintes passagens: Georgius de Nitheweie appellat Estmarum de Netheweye quod assultavit eum una cum Thoma filio suo et vulneravit eum in brachio et uxorem ejus similiter, et quod hoc fecit nequiter et in felonia et in pace domini Regis offert probare versus eum per corpus sicut curia consideraverit. Postea vero dedicit quod non appellat Estmarum de facto immo Thomam de facto et Estmarum de vi; et ideo Thomas capiatur. Post venit thomas et Georgius appellat eum quod nequiter et in felonia et in pace domini Regis vulneravit eum in brachio de nocte die dominica proxima post Pentecostem anno primo Regis Henrici, et hoc paratus est probare versus eum sicut curia consideraverit, sicut homo mahemiatus de plaga illa, et si non sit mahemium paratus est probare per corpus suum sicut curia consideraverit. (MAITLAND, 1884, p. 21-22; Vita Wulfstani, 1928, p. 170-171). A apelação é dirigida contra Estmar e seu filho, Thomas. Eis um dado significativo envolvendo a constituição social do sujeito jurídico. Tendo vista as limitações de um artigo científico e a coesão do argumento central aqui desenvolvido, optei por não explorar tal tema.

${ }^{16}$ As citações ao longo do parágrafo foram retiradas desta passagem: Conueniunt in campum die prefixo iusticiarii et plebs innumerosa sexus promiscui pugiles quoque cum armaturis suis preparati. Stat Georgius in multitudine fortitudinis sue confisus, et in monomachie disciplina agilis et expeditus. Stat sex aduerso Thomas in domino confidens, gloriosam dei genitricem Mariam et beatum Wlstanum in adiutorium sui deuotius inuocans; pretérita plangens, emendatiorem uitam promittens; lacrimasque in id ipsum copiosius infundens. (Vita Wulfstani, 1928, p. 170)

${ }_{17}$ Para as citações documentais e a descrição do combate empregada ao longo do parágrafo, ver a seguinte passagem: Post orationem completam congrediuntur uicissim, uulnerantur et uulnerant; set in Thomam pessima semper queque declinant. Set quanto magis grauatur; tanto in maiorem sancti Wlstani excitatur deuotionem. Post multos tandem insultus Thomas multis attritus uulneribus a Georgio capitur, humi proicitur; oculoque dextro fere eruto uictum se compulsus confitetur. Et odioso monomachie uerbo irreuocabiliter emisso; exuuiis pugillaribus a uictore exuitur, et satis nudus in campo relinquitur. (Vita Wulfstani, 1928, p. 170-171)

${ }^{18}$ As citações documentais ao longo do parágrafo foram retiradas deste trecho: Cumque de consuetudione regni suspensione fuisset obnoxius, iusticiarii tamen misericordiam iudicio commiscentes, uirilium ementulatione et pariter exoculatione illum dignum iudicauere. Huius iudicii exsecutionem propinquis et affinibus uictoris iniunxere. (Vita Wulfstani, 1928, p. 171)

${ }_{19}$ As citações documentais ao longo do parágrafo foram retiradas da seguinte passagem: Qui libidine uindicte magis quam amore iustice coram iusticiariorum ministris ad hoc relictis, et multitudine curiose plebis ad tale spectaculum libenter affluentis; unum oculorum statim et leuiter eruerunt. Alterum uero a Georgio ualde detritum cum magna difficultate, cum magna pacientis anxietate; uix et tandem effoderunt. Instrumentum exoculatorium bis uel ter preacuentes, et usque ad cerebrum illud maliciose trahicientes; ut uitam cum uisu pariter extinguerent. Miser igitur Thomas nichil sibi residuum estimans, nisi ut menis oculos ad deum leuaret; semper et continue beatam Mariam et beatum Wlstanum uehementer clamans inuocabat. Apparitores autem rem crudeliter peragentes, pupilas effossas et neruis adhuc super faciem dependentes uidentibus multis presciderunt; et in campum proiecerunt. Testiculos nichilominus a follibus suis erutos et prescisos longius proiecerunt; ita ut iuuentus lasciua illos inter mulierculas huc illucque pedibus suis reciproce iactaret. (Vita Wulfstani, 1928, p. 171)

${ }^{20}$ As citações documentais ao longo do parágrafo foram retiradas do seguinte trecho: Hiis igitur circa miserum Thomam miserabiliter peractis, abierunt quique in sua; ipso semi-uiuo relicto. Volutat se miser in suo sanguine, qui a plagis impositis tanto fluxu decurrit, ut fere exanimis ibi supremum crederetur exsuflaturus spiritum. Verumptamen ne canibus ibidem deuorandus relinqueretur, ab aliquibus eius 
miserias miserantibus compulsus abducitur; magis subportantium brachiis quam suis pedibus adiutus. [...] Set tibi pie Iesu tibi derelictus est pauper, et quem mundus pater abicit pupillo tu eris adiutor, sic misericorditer puniens; ut iuste miserearis. Etenim uniuerse uie tue, misericordia et ueritas. (Vita Wulfstani, 1928, p. 171)

${ }^{21}$ Quanto às citações documentais ao longo do parágrafo, foram retiradas da passagem a seguir: Erat autem in illo hospitali mulier quedam Ysabel nomine, pauperum specialiter addicta obsequiis. Hec contra magistri sui et fratrum eiusdem loci prohibitiones dicti Thome curam egit; occulte autem propter metum eorum. Sic prospiciente deo, ut ubi habundauit miseria; superhabundaret et gratia. Hec uacuas oculorum fossas a fecibus humorum illuc defluentium cotidie samisintiis suis sollicite purgabat, et uulneribus illius exemplo Samaritani mitigatiua et sanatiua procurabat. [...] Post multiplicatas igitur in hunc modum orationes, inmisit dominus soporem in Thomam adeo tamen tenuem, ut ignoraret na uigilaret uel dormiret. Et ecce domus tota inedicibili fulgore ei resplendere uidebatur. [...] Thomas gaudens se nouo amictus lumine et sine oculis posse lidere plusquam credi possit admirans; in lumen illud attentius intendit. Apparuit ei ueri luminis mater et perpetua uirgo Maria tanta claritate refulgens, quod nec auderet nec posset faciem eius intueri. Et enim plusquam cornuta ei uidebatur. Apparuit et cum ipsa set eius sequens uestigia beatus Wlstanus pontificalibus indutus, miro; sed longe impari fulgore resplendens. Cumque lectulo eius appropinquarent, datis super eum benedictionibus suis transierunt; et transeuntes preterierunt. Thomas igitur ab extasi reuocatus; subito clamore omnes qui in domo erant perculit, sanctam Mariam et sanctum Wlstanum adesse proclamans; [...]. (Vita Wulfstani, 1928, p. 172-173)

${ }^{22}$ As citações documentais ao longo do parágrafo foram coligidas deste trecho: Cumque aliquandiu uigilans iacuisset, et de tam gloriosa uisione intra se cogitasset; ceperunt ei palpebre et omnia insuper uulnera que in duello susceperat tam uehementer pruirire quod a scalpendo uix potuit manus continere. Vocata igitur memorata sorore petiit oculorum fossas et cetera uulnera sua lauari, ut uel sic suo consuleretur pruritui. Illa igitur ex deuotione obediens, solutis ligami nibus quibus emplastrum medicinale oculis eius appositum ligabatur; aquam parauit ad lauandum. Ille autem more impaciens et ad parietem se uertens iniectis digitis palpebras detraxit, ne nimis prepropere sanarentur; antequam fuxlus humorum restringeretur. Et ecce sub ostio in cuius transuerso lectus eius fuerat collatus lumen subintrans contemplatur; stupet et miratur. Et sibi no credens, in excessum mortis sicut paulo ante raptum se suspicatur. Set oculos circumuoluens, omnia obiecta contuetur; manus admotas clare satis conspicatur. Et in latus aliud uersus plateam se uertens, transeuntes et circumstantias sicut olim aperte contemplatur. [...] Propiusque accedentes nouas set modicas in fossarum profunditate contuentur pupilas; tanquam duas prunulas. [...] Creuerunt de die in diem; usque ad competentem quantitatem. (Vita Wulfstani, 1928, p. 172-173)

${ }^{23}$ Quin immo omnia uulnera sua que quidem multa receperat in duello sicut eundem habuerunt medicum, ita curationis sue idem habuerunt momentum. (Vita Wulfstani, 1928, p. 174)

${ }^{24}$ As citações ao longo do parágrafo foram retiradas do seguinte trecho: Iussit ergo capellanum suum monachum licet propter uerecundiam renitentem, uirilia palpare; et ipsum si restituta essent certificare. [...] Quidni monachus obediret? Genibus flexis manus admouit; palpauit, et sic esse sicut relatum fuerat; exclamauit. Episcopus igitur pre gaudio lacrimas ubertim effundens; palpabo inquit et ego, no ut incredulitati mee satisfaciam; set ut tanti miraculi uerus et fidelis testis fiam. Palpauit, sic esse inuenit; et credidit. Quo facto, dedit gloriam deo; et reascenso equo, ibat uiam suam gaudens. (Vita Wulfstani, 1928, p. 174-175. Ver ainda: Annales de Wigornia, 1869, p. 413-414)

${ }^{25}$ Et ut tantum miraculum sui quidem magnitudine stupendum cresceret, autentico testimonio maiorum; [...]. (Vita Wulfstani, 1928, p. 174) 